$20^{\circ}$

$11-14$

DR 1044

UCRL- 51650

\title{
POWER EFFICIENCIES OF NEUTRAL BEAM SYSTEMS
}

J. H. Fink

September 11,1974

Prepared for US Atomic Energy Commission under contract Wa. W-7405-Eng-48

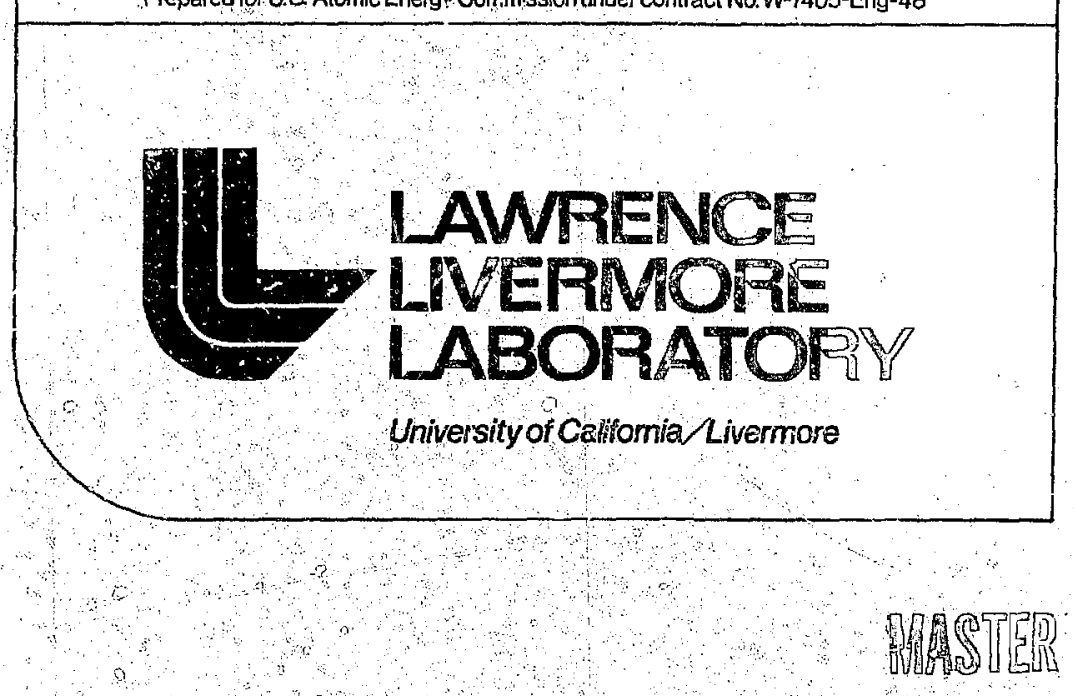




\section{NOTICE}

"This report was prepared as an accoult of work sponsozed by the United Slates Governnent. Neithet the United States nor the Untted States Atomic Energy Commission, nor any or their employdes, nor tsny of their contrictors, subcontractors, or their omploses mers employecs, makes any warranty, express or implicd, or assumits atyy legal liability or responsibility lar the accurdey, corte pleteness or usefulness of any information, apparatus, product or process. disclosed, of represents that its use would not inifinge privately
owned rights."

Printed in the United States of America Available from

National Technical Information Service

UI.S. Department of Commerce 5285 Port Royal Road

Springfield, Virginia 22151

Price: Printed Copy $\$$; Microfiche $\$ 1.45$

\begin{tabular}{r} 
Pages \\
\hline $1-50$ \\
$51-150$ \\
$151-325$ \\
$325-500$ \\
$501-1000$
\end{tabular}

NTIS

Selling Price

$\$ 4.00$

$\$ 5.45$

$\$ 7.60$

$\$ 10,50$

$\$ 13.60$ 
TID-4500, ve -20

Contrulled Thermonuclear Processeb

and Plasme Physics

\title{
논 \\ LAWRENCE LNEFWORE LAEORATOFY

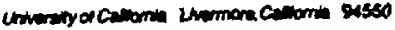

\section{UCRL-51650 \\ POWER EFFICIENCIES OF NEUTRAL BEAM SYSTEMS}

\author{
J. H. Fink
}

MS. date: ieptember is, J974

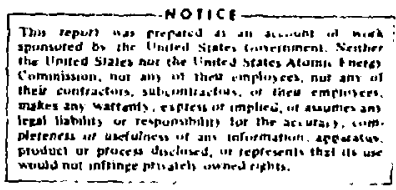




\section{Liat of Symbole}

$11^{0} \quad b^{0}$, neutral alonic deuterium curtent

$\left.11_{2}^{0} \quad(1)_{2}^{0} \cdot 10_{3}^{0}\right)=$ neutral nolecular deuterium curress

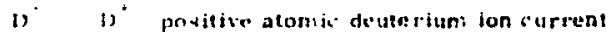

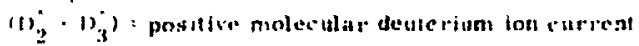

$11^{\circ} \quad 1^{\circ}$ thestise Htomin duterius ion chrient

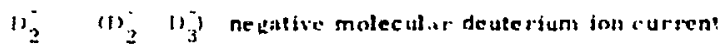

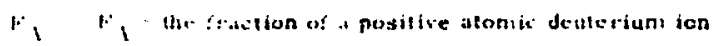
heam that can he neutralized by repeated pistses throuth an tdeal motializer.

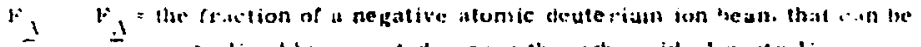
neutralized by mpeated passes through an isterl neut ralize:

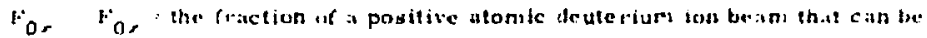
netutralizud in a single pass through an joleal nelv ralize:

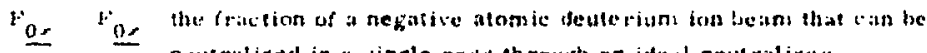
neutralized in a single pass through an ide.al neut rali:er.

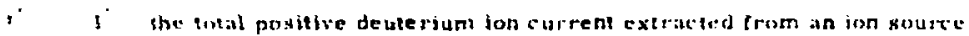

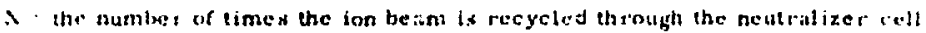

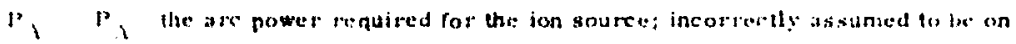
only dariat the beatis pulse

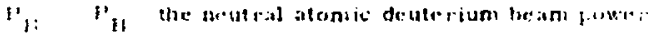

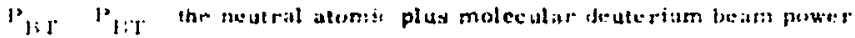

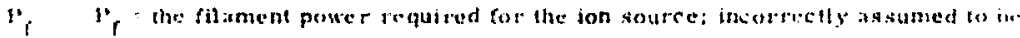
an only durimg the betam nul ise

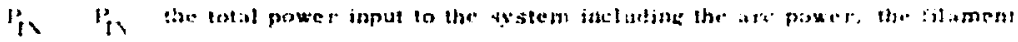

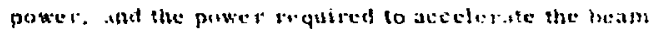

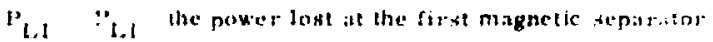

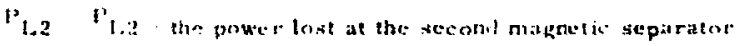

I'ix l'if the ubused bean power that is recosered

4 it the conergy of the final heam

"l, $F$. the beam enerst coming from the source

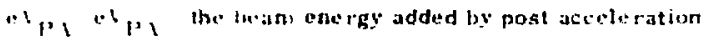

"I the tration of positive atonic deuteriunt ions in the ham. as extracted and the souree 
$\eta_{-}=$the fraction of a positive atonic deuterium ion beam that becomes negative through double charge exchange in a cesium or sodium vapor cell

$\epsilon_{1}=$ the fraction of beam eluergy, lost at the first separator, which is recovered

$\epsilon_{2}=$ the fraction of baam ene rgy, logt at the second separator, which is recovered

$\epsilon_{1}=$ the f raction of an ion beant that is effectively retained through a single pass a round an ion beann recycling unit 


\title{
POWER EFFICIENCIES OF NEUTRAL BEAM SYSTEMS
}

\author{
Abstract \\ The power efficiencies of several \\ neutral beam systems are presented as \\ functions of beam energy. Direct injection \\ systems are found to be most efficient at \\ low beam energies while negative ion sys- \\ tems are best at high energies. In the \\ intermediate range, post acceleration is \\ best.

\section{Introduction} \\ Although there are many ways to eval- \\ uate a neutral beam system, an elemen- \\ tary comperison of the power efficiencies \\ of three concepts of neutral beam genera- \\ tion (i.e., direct injection, Figs. 1, 2, and \\ 3; post acceleration, Figs, 4, 5, and 6; \\ and negaitive ion conversion, Figs. $7, B$, and \\ and 9) is presented, along with two methods \\ of enhancing their efficiencies $(i, e .$, un- \\ used beam pow or recovery and ion beam \\ recycling. For each of these schemes, \\ as well as for several combinations of \\ the $m$, efficiencies were calculated over a \\ range of beam esergies from 20 to $240 \mathrm{keV}$.
}

\section{Assumptions}

Since most of these systems have never been tried, certain assumptions had to be made to evaluate their performance. These assumptions are:

- First, an ion source of the Berkeley type ${ }^{1}$ was considered typical. It consists of 86 filaments, each requiring $25 \mathrm{~A}$ at $12 \mathrm{~V}$, and is operated with a $3000-\mathrm{A}$ arc at $50 \mathrm{~V}$ to deliver a $70-\mathrm{A}$ ion beam that is roughly $75 \%$ atomic deuterium. Thus,

$$
n_{1}=0.75 \text {. }
$$

Although the operating period of the filament and arc is longer than that of the beam, the following approximation was used:

$$
\frac{P_{f}+P_{A}}{I^{+}}=2.5 \mathrm{~kW} \mathrm{~A}^{-1}
$$

This simplifies the analysis while it does not make much difference at the beam energies of interest.

- To obtain negative ions via a process of double charge excharge, in a cesium cell, ${ }^{2}$ it was assumed that the incident ion beam is extracted from the source at

$$
V_{E}=1.75 \mathrm{kV}
$$

resulting in a fraction of negative ions such that

$$
\eta_{-}=0.2 \text {. }
$$




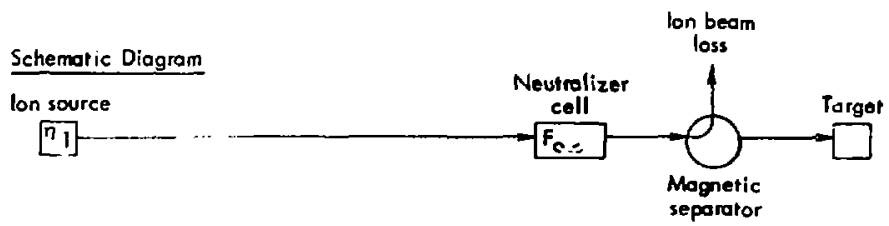

Pertinent Relationships

\begin{tabular}{|c|c|c|}
\hline & Current (A) & Power (kW) \\
\hline Torget & $\left\{\begin{array}{l}D^{0}=n_{1} F_{0.0} 1^{+} \\
\left.\left(0_{2}^{0}+D_{3}^{0}\right)=\left(1-n_{1}\right) F_{000}\right)^{+}\end{array}\right.$ & $\begin{array}{l}P_{B}=D^{0} V \\
\left(P_{B T}-P_{B}\right)=\left(D_{2}^{0}+D_{3}^{0}\right) V\end{array}$ \\
\hline lon beam loss & $\left\{\begin{array}{l}D^{+}=n_{1}\left(1-F_{0 \infty}\right) 1^{+} \\
\left(D_{2}^{+}+D_{3}^{+}\right)=\left(1-\eta_{1}\right)\left(1-F_{0 x}\right) 1^{+}\end{array}\right.$ & $P_{L}=\left(1-F_{0 \infty}\right) I^{+} V$ \\
\hline Power input & & $P_{I N}=P_{f}+P_{A}+1^{+} V$ \\
\hline
\end{tabular}

\section{Performonce}

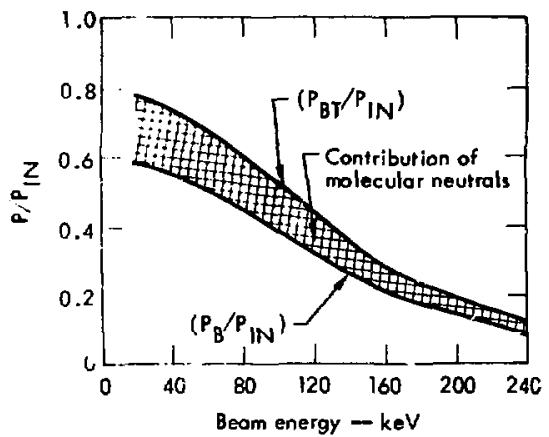

Fig. 1. Direct injection. 


\section{Schemotic Diagram}

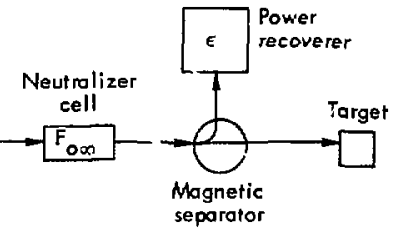

\section{Pertinent Relationships}

\begin{tabular}{|c|c|c|}
\hline & Current (A) & Fower (kW) \\
\hline Target & $\left\{\begin{array}{l}D^{0}=\eta_{1} F_{0 \infty} 1^{+} \\
\left(D_{2}{ }^{0}+D_{3}{ }^{0}\right)=\left(1-\eta_{1}\right) F_{0 \infty} I^{+}\end{array}\right.$ & $\begin{array}{l}P_{B}=D^{0} V \\
\left(P_{B T}-P_{B}\right)=\left(D_{2}{ }^{0}+D_{3}{ }^{0}\right) V\end{array}$ \\
\hline Ion beam loss & $\left\{\begin{array}{l}\mathrm{D}^{+}=n_{1}\left(1-\mathrm{F}_{\mathrm{O}-0}\right) \mathrm{I}^{+} \\
\left(\mathrm{D}_{2}{ }^{+}+\mathrm{D}_{3}^{+}\right)=\left(1-n_{1}\right)\left(1-\mathrm{F}_{\mathrm{ONo}}\right) \mathrm{I}^{+}\end{array}\right.$ & $P_{L}=\left(1-F_{0.0}\right) I^{+} V$ \\
\hline Power input & & $P_{1 N}=P_{f}+P_{A}+I^{+} V$ \\
\hline Power recovery & & $P_{R}=\epsilon\left(1-F_{0,0}\right) J^{+} V$ \\
\hline
\end{tabular}

\section{Performance}

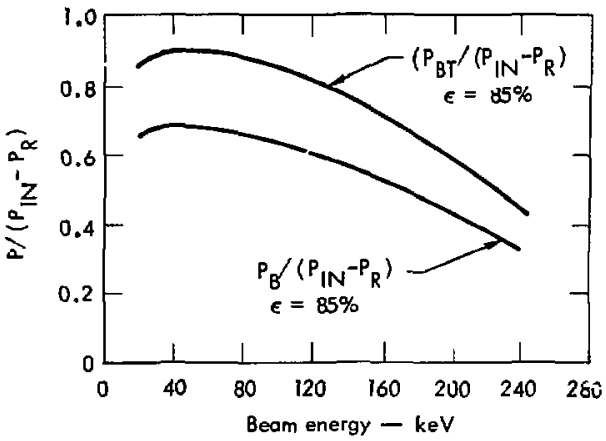

Fig. 2. Direct injection with unused beam power recovery. 
Schemotic Diagram

Beam recycle:

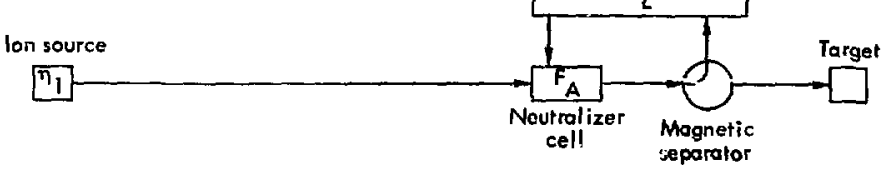

Pertinent Relationships

\begin{tabular}{|c|c|c|}
\hline & Curient (A) & Power $(k W)$ \\
\hline Target & $\left\{\begin{array}{l}D^{0}=\eta_{1} F_{A} I^{+} \\
\left(D_{2}{ }^{0}+D_{3}{ }^{0}\right)=\left(1-\eta_{1}\right) F_{0,0} I^{+}\end{array}\right.$ & $\begin{array}{l}P_{B}=D^{0} V \\
P_{B T}=\left(0^{0}+D_{2}{ }^{0}+D_{3}{ }^{0}\right) V\end{array}$ \\
\hline lon beam lass & $\begin{array}{l}D^{+}=\eta_{1}\left(1-F_{A}\right) I^{+} \\
\left(D_{2}^{+}+D_{3}^{+}\right)=\left(1-\eta_{1}\right)\left(1-F_{\text {oos }}\right) I^{+}\end{array}$ & $\begin{array}{c}P_{L}=\left[\left(1-\eta_{1}\right)\left(1-F_{O x}\right)+\right. \\
\left.\eta_{1}\left(1-F_{A}\right)\right] I+V\end{array}$ \\
\hline Power inpus & & $P_{I N}=P_{f}+P_{A}+I^{+} V$ \\
\hline & $F_{A}=\left(F_{0 \infty}\right)\left\{\frac{1-\left[\epsilon_{L}\left(1-F_{0 \infty}\right)\right]^{N}}{1-\epsilon_{L}\left(1-F_{0 \infty}\right)}\right\}$ & \\
\hline
\end{tabular}

Performance

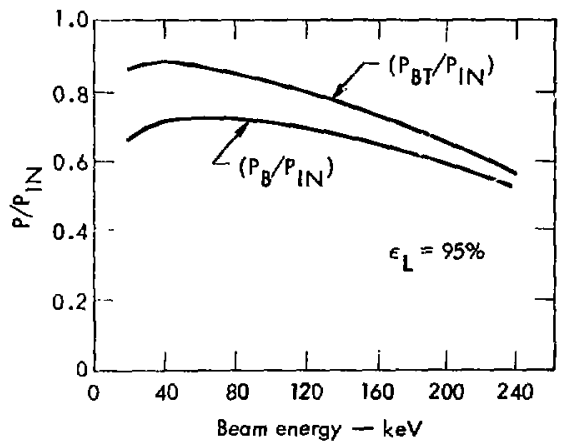

Fig. 3. Direct injection with ion beam recycling. 
Schematic Diggrom

lon source

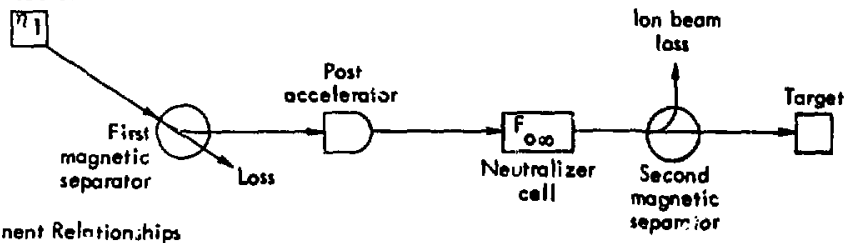

Pertinent Relationships

\begin{tabular}{|c|c|c|}
\hline & Current (A) & Power (kW) \\
\hline Target & $0^{0}=n_{1}, F_{0 \infty} 1^{+}$ & $P_{B}=n_{1} f_{0,0} I^{+} V$ \\
\hline First sepomtor loss & $\left(D_{2}{ }^{+}+O_{3}{ }^{+}\right)=\left(1-n_{1}\right) 1^{+}$ & $\left.P_{L I}=\left(1-r_{i}\right)\right) 1^{+} V_{E}$ \\
\hline Second seporator los: & $D^{+}=n_{1}\left(1-F_{0 \infty}\right) l^{+}$ & $P_{12}=n_{1}\left(1-F_{0 x}\right) 1^{+} b$ \\
\hline Power input & & $P_{I N}=P_{f}+P_{A}+I^{+} V_{E}+\eta_{1}$ \\
\hline
\end{tabular}

\section{Performance}

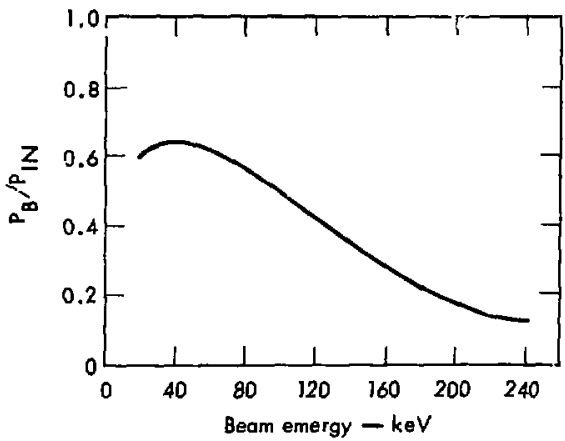

Fig, 4. Post acceleration system. 
Schematic l)iagram

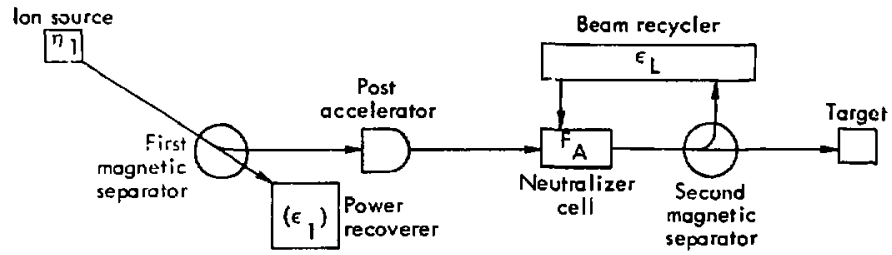

Pertinent Reloticnships

\begin{tabular}{|c|c|c|}
\hline & Current (A) & Power (kW) \\
\hline Torget & $D^{0}=\eta_{1} F_{A} I^{+}$ & $P_{B}=\eta_{1} F_{A} I^{+} V$ \\
\hline First separator loss & $\left(D_{2}{ }^{+}+D_{3}{ }^{+}\right)=\left(1-n_{1}\right) 1^{+}$ & $P_{L I}=\left(1-n_{1}\right) I^{+} V_{E}$ \\
\hline Secoi,d separator loss & $D^{+}=n_{1}\left(1-F_{A}\right) l^{+}$ & $P_{L_{2}}=\eta_{1}\left(1-F_{A}\right) l^{+} V$ \\
\hline Power input & & $\begin{aligned} P_{I N}=P_{f} & +P_{A}+1^{+} V_{E} \\
& +\eta_{1} 1^{+} V_{P A}\end{aligned}$ \\
\hline Power recovery & & $\left.P_{R}=\epsilon_{1}\left(1-r_{I}\right)\right]^{+} V_{E}$ \\
\hline
\end{tabular}

Performance

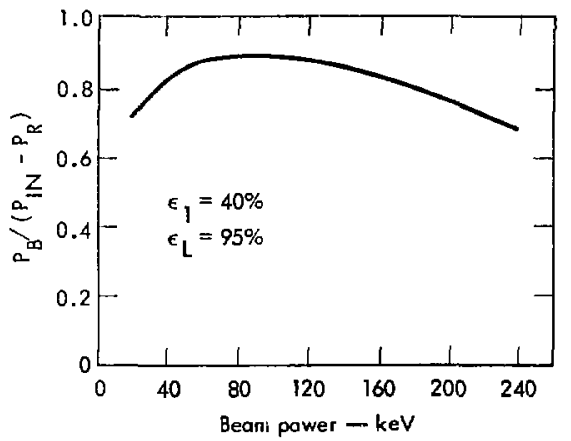

Fig. 5. Post acceleration system with ion beatn recycling. 


\section{Schematic Diagram}

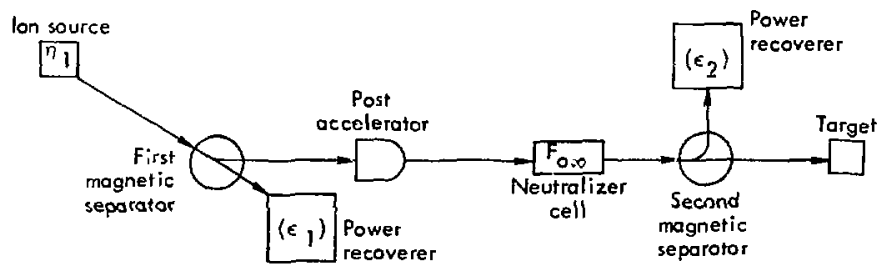

Pertinent Relationships

\begin{tabular}{|c|l|c|}
\hline & Current (A) & Power (kW) \\
\hline Target & $D^{0}=\eta_{1} F_{O \infty} I^{+}$ & $P_{B}=\eta_{1} F_{O \infty} I^{+} V$ \\
Second separator loss & $D^{+}=\eta_{1}\left(1-F_{O \infty 0}\right) I^{+}$ & $\begin{array}{l}P_{L I}=\left(I-\eta_{1}\right) I^{+} V_{E} \\
P_{L 2}=\eta_{1}\left(I-F_{O \infty}\right) I^{+} V\end{array}$ \\
\hline Power input & & $P_{I N}=P_{f}+P_{A}+I^{+} V_{E}+\eta_{1} I^{+} V_{P A}$ \\
\hline Power recovery & & $P_{R}=E_{1} P_{1}+E_{2} P L_{2}$ \\
\hline
\end{tabular}

\section{Performance}

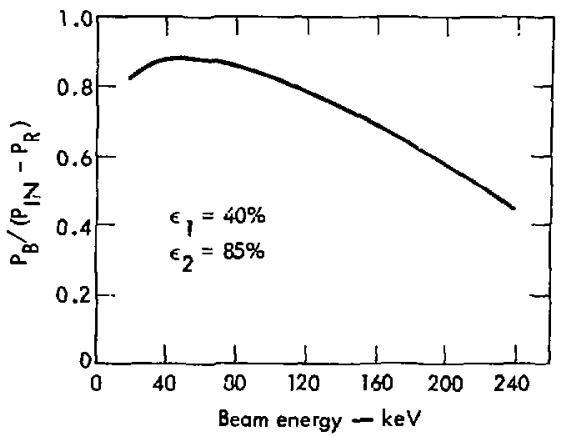

Fig. 6. Post anceleration system with unuced beam power recovery. 
Schematic Diagram

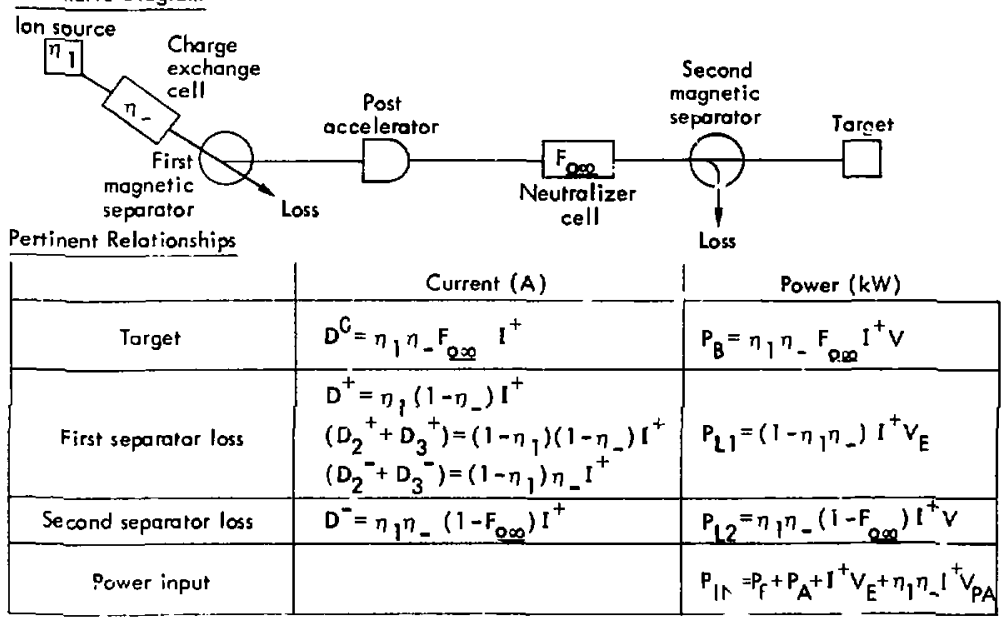

\section{Performance}

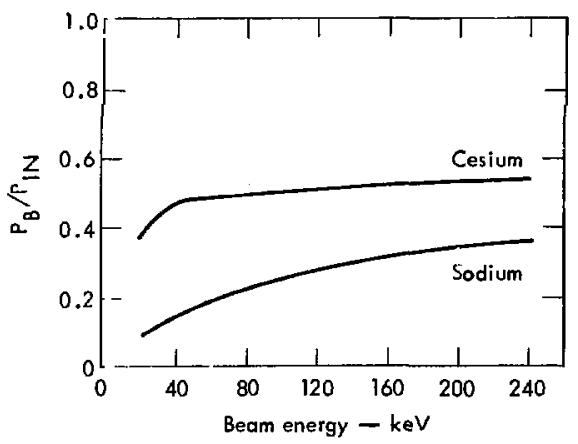

Fig. 7. Negative ion system. 
Schematic Diagram

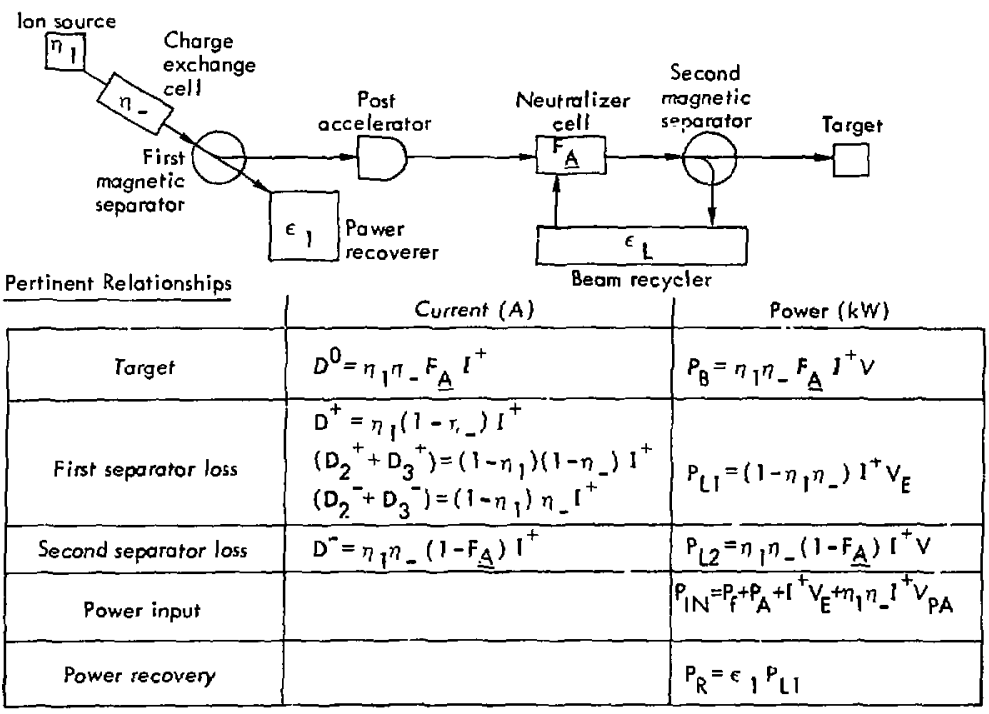

\section{Performance}

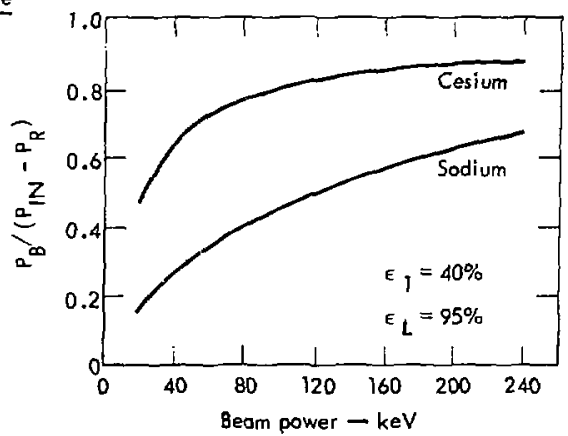

Fig. 8. Negative ion system with ion beam recycling. 


\section{Schematic Diagram}

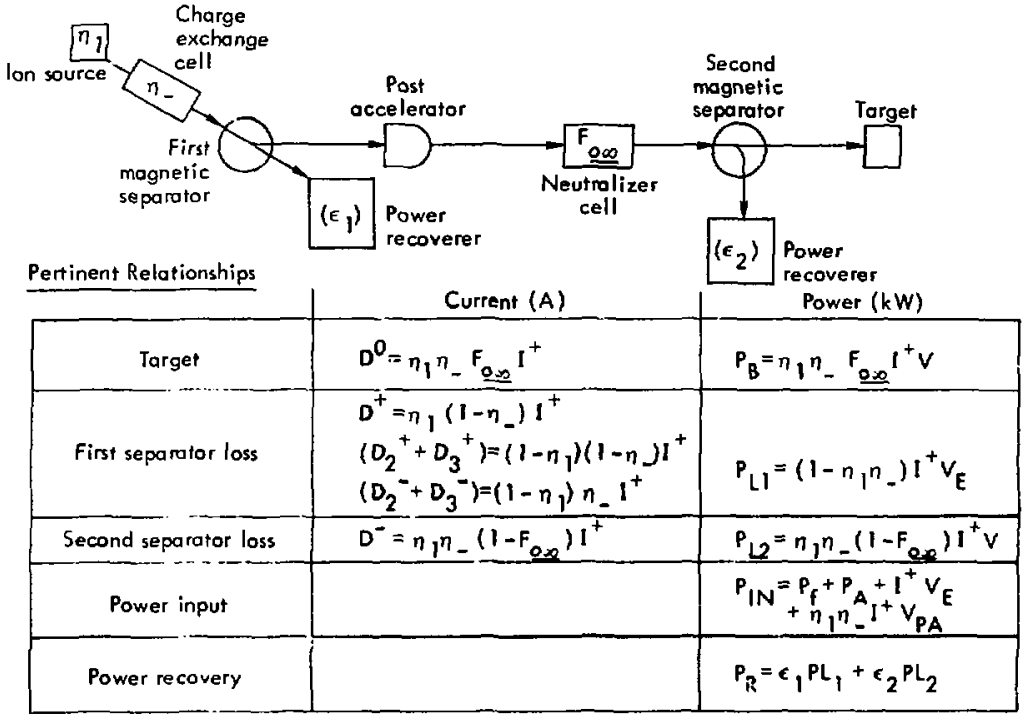

\section{Performonce}

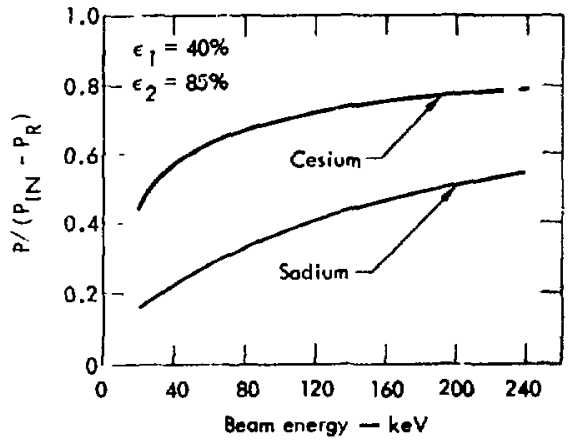

Fin. A. Negatise ion system with unused bean power recovery. 
Similarly for as sodium cell,

$$
v_{E}=10 \mathrm{kV}
$$

whereby

$$
n_{-}=0.1 \text {. }
$$

- The neutralizer cells were consicued to operate at their maximum efficiency at values of $F_{0 \infty}$ and $F_{0 \infty}$, which approach those shown in Fig. 3 of Ref. 3.

Meanwhile, the fraction of a positive ion beam that could be neutralized by continuously circulating through a neutralbize cell was determined by recognizing that the ion current available for the second pass would be $\left[\epsilon_{L}\left(1-F_{0 x}\right)\right]$ times the current in the first pass.

Thus for 1 passes

$$
1_{X}=\left[L_{L}^{\left(1-F_{00}\right)}\right]^{N-1} I_{1} \text { ampere, }
$$

and the total current passing through the neutralizer, is

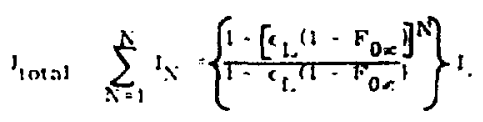

live clerinition

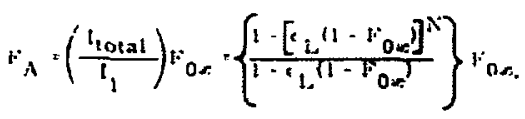

If we let

$$
1-\left[c_{1}\left(1-E_{0 r}\right]^{N}=0.5 n\right. \text {. }
$$

the required passes through the neutral ier becomes

$$
\left.x=\frac{-3.4}{\log \left[L^{1}-F_{0}\right]}\right]
$$

By direct analogy, by substituting $F_{0 \infty}$ for $F_{0 x}$ and $F_{\underline{A}}$ for $F_{A}$, these reltionships become applicably. for negative ions.

- Because of the relatively low energy and the possibility of an unwanted molecular neutral beam component. the unused beam ene ray at the fir, st magnetic separator is recovered hermodynamicalty at in efficiency of

$$
c_{1}=40^{5} \text {. }
$$

However, at the sec and nathetic separator direct electicinl recovery is anticipated at a much bette: effictersy. i. e. .

$$
y_{2}=85 x^{2} .
$$

- Finally. the ultimate beam energy equals that which it initially obtained upon extraction from the is n source. plus whatever etseray was derived from post aceoleleration. That:

$$
1 \because !=\mid v_{t}: v_{p A} i n t .
$$

.11. 


\section{Conclusion}

The resuts of thrse dalculations are shown in Figs. I through 9. The same curves are l'udrisn scueral times, Figs. 10 through 13 . tu povide: a more vivid comparison of these tarious apprarises. Al though these griphi need little explanalion. it must be cmplisisized that some of the assunplishis used to generate these curves are questiunable, at least quantititivels. Therefore, only the most gen+ cal sunclusions can he drawn from this work.

11:o, thert: a: 0 firctors other than puwil utilization thit ihould be reviewed. These include ros cificiency. development riak and cost, capilal cosis, maximum

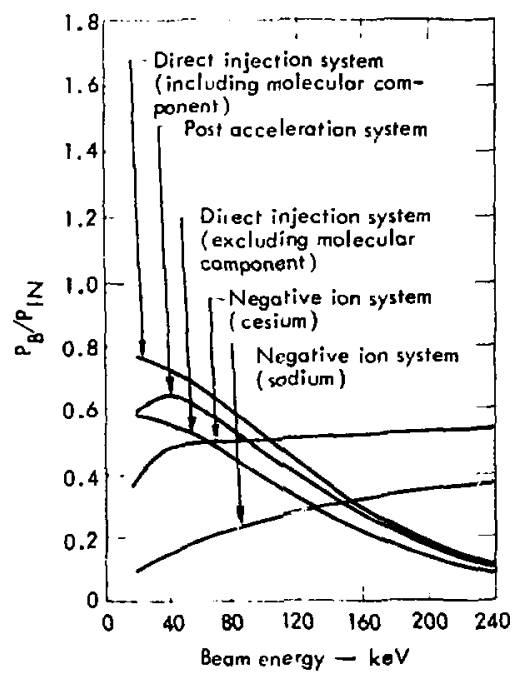

Fif. 10. Cimpatison of neutsal heam sys tents without dificiency enbancement. realizable power densily and bean uniformity at the target, reliability. and any other consideration that nay be pertinent to a particular situetion.

It is clear from Figs. 10 through 13 that if the molecular component of the neutral beam makes a useful contribution, the direct injection system without enhancement is reasnnably efficient at beam energies less than $k \mathrm{k} k \mathrm{k}$. If the molecular component is untesirable the post acceleration sistem should bo considered, except at enorgies greater than $100 \mathrm{keV}$ where the negative irun system is best, irrespective of the method of efficiency enhancoment.

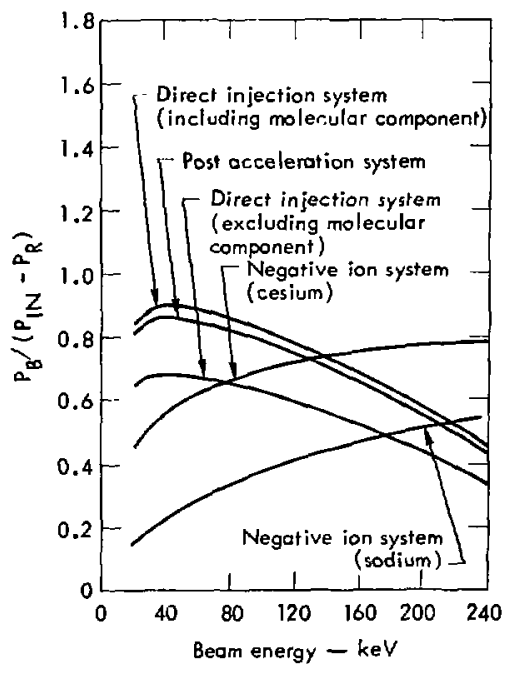

Fig. 11. Comparison of neutral beam systems with unused beam power recovery. 


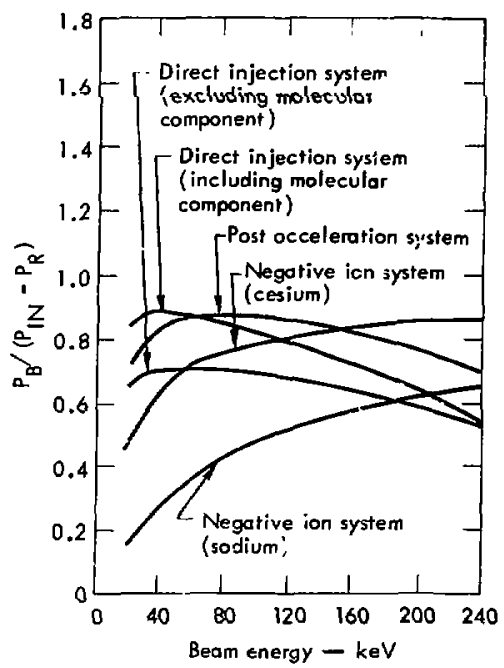

Fig. 12. Comparison of neutral beam systems with ion beam recycling.

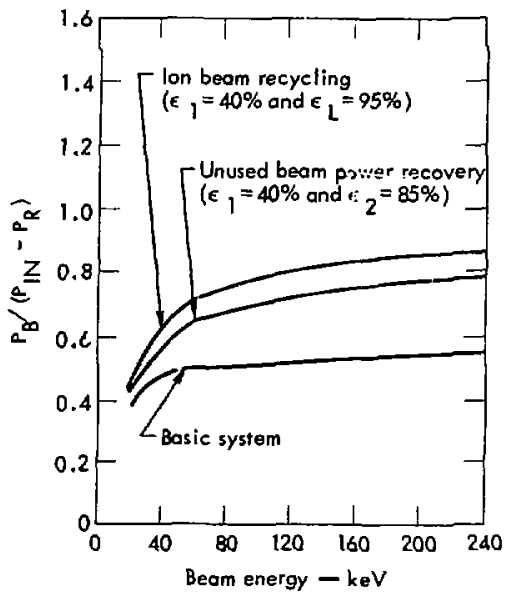

Fig. 13. Comparison of efficiency enhancement on a cesium negative ion system. 


\section{References}

1. W. R. Baker, K. H. Berkner, W. S. Cooper, K. W. Ehlers, W. F. Kunkel, R. V. Pyle, and J. W. Sterns, "Neutral Beam Ressarch and Development at LBL Berkeley," in 5th Symp. on Eng. Probl. of Fusion Res. (Frinceton, New Jersey, 1973).

2. J. F. Osher, F. J. Gordon, and G. W. Hamilten, "Production of Intense Negative Ion Reams," in Proc. of the 2nd Inter. Conf. on Ion Sources, (Vienna, Austria, 1972).

3. K. H. Jicutiner, R. V. Pyle and J. W. Stcarns, "Mixed Species in Intense Neutral Beams," in Proc. of the 1st Topical Meeting on the Technol. af Contr. Nucl. Fusion, (San Diego, California, 1974). 